Article

\title{
Synthesis of 1,5-Functionalized 1,2,3-Triazoles Using Ionic Liquid/Iron(III) Chloride as an Efficient and Reusable Homogeneous Catalyst
}

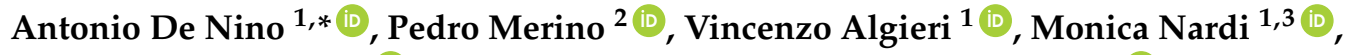 \\ Maria Luisa Di Gioia ${ }^{4}$ (D), Beatrice Russo ${ }^{1}$, Matteo Antonio Tallarida ${ }^{1}$ (D) \\ and Loredana Maiuolo ${ }^{1, *}$ \\ 1 Dipartimento di Chimica e Tecnologie Chimiche, Via P. Bucci, cubo 12C, Università della Calabria, \\ 87036 Rende (CS), Italy; vincenzo.algieri@unical.it (V.A.); monica.nardi@unical.it (M.N.); \\ russobea@gmail.com (B.R.); matteotallarida@gmail.com (M.A.T.) \\ 2 Instituto de Biocomputacion y Fisica de Sistemas Complejos (BIFI), Universidad de Zaragoza, \\ Campus San Francisco, 50009 Zaragoza, Aragon, Spain; pmerino@unizar.es \\ 3 Dipartimento di Agraria, Università Telematica San Raffaele, Via di Val Cannuta, 247, 00166 Roma, Italy \\ 4 Dipartimento di Farmacia e Scienze della Salute e della Nutrizione, Edificio Polifunzionale, \\ Università della Calabria, 87036 Rende (CS), Italy; maria_luisa.digioia@unical.it \\ * Correspondence: denino@unical.it (A.D.N.); maiuolo@unical.it (L.M.); Tel.: +39-0984-492043 (A.D.N.)
}

Received: 31 July 2018; Accepted: 24 August 2018; Published: 29 August 2018

\begin{abstract}
An efficient, eco-compatible, and very cheap method for the construction of triazoles via eliminative azide-olefin cycloaddition (EAOC) reaction has been developed by a catalytic system, $\mathrm{IL} / \mathrm{FeCl}_{3}$, offering a highly regioselective approach to structurally diverse 1,5-disubstituted 1,2,3-triazoles in up to $95 \%$ yield. This strategy features the reuse of a catalytic system through simple operations. Mechanistic studies indicated that an asynchronous concerted dipolar cycloaddition-elimination process might be involved.
\end{abstract}

Keywords: azides; [3 + 2] cycloaddition; EAOC reaction; electron-deficient olefins; 1,2,3-triazoles

\section{Introduction}

Triazoles are five-member $N$-heterocyclic compounds bearing three nitrogen atoms in the ring. They exist in two isomeric forms, namely, 1,2,3-triazoles and 1,2,4-triazoles, and are an important nucleus for the development of drugs, mainly because they are resistant to oxidation, reduction, and hydrolysis in both acidic and basic conditions because of their aromatic nature [1]. Their active participation in hydrogen bond formation, dipole-dipole, and $\pi$-stacking interactions can mimic peptide bonds, enhancing their binding ability with different biological targets [2]. Therefore, triazoles represent a significant class of nitrogen compounds with important biological properties, such as antibacterial, anticancer, antivirus, antimalarial, anti-inflammatory, and antituberculosis [3,4]. In particular, 1,2,3-triazoles have found a broad spectrum of biological applications such as $\beta$-lactum antibiotic tazobactum, cefatrizine, and anticancer compound carboxyamidotriazole (CAI), which are some drugs available on the market [5].

Many approaches for the synthesis of 1,2,3-triazoles have been developed so far. The conventional synthetic method of 1,2,3-triazoles is 1,3-dipolar cycloaddition of Huisgen between alkynes and organic azides [6], which generally provides a mixture of 1,4- and 1,5-regioisomers. The most important developments were achieved in this area by the copper catalyzed azide-alkyne cycloaddition (CuAAC) to obtain the 1,4-disubstituted isomer and the ruthenium azide-alkyne cycloaddition (RuAAC) to achieve the 1,5-disubstituted isomer [7-11]. However, the (CuAAC)-catalyzed process only works 
with terminal alkynes, whereas the (RuAAC)-catalyzed reaction requires the use of very expensive ruthenium salts as catalyst.

As an alternative approach to azide-alkyne cycloaddition, electron-deficient olefins were proposed to replace alkynes because of their easy availability and low-cost preparation $[12,13]$. The azide-olefin cycloaddition furnishes triazoline, an unstable compound that readily decomposes but may be transformed into the stable triazole by eliminative azide-olefin cycloaddition (EAOC). In this process, the olefin carrying a leaving group reacts with the azide to form the intermediate triazoline that gives the corresponding triazole by elimination reaction [14].

Nitroolefins, as versatile starting materials, are excellent dipolarophiles to synthesize triazoles by EAOC cycloaddition. In fact, the presence of the electron-withdrawing nitro group improves the 1,3-dipolar cycloaddition process, favouring the formation of 1,2,3-triazoles due to the fast nitrous acid loss through the elimination step (Scheme 1).

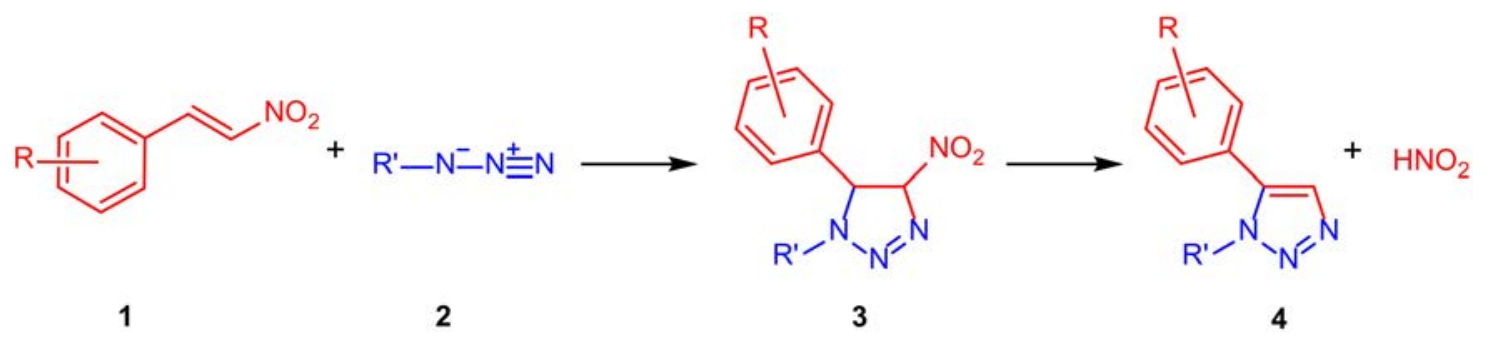

Scheme 1. Eliminative azide-olefin cycloaddition (EAOC) cycloaddition to synthesize 1,5-disubstituted 1,2,3-triazoles.

Over the past decade, many researchers have shown substantial interest in the EAOC process of nitroolefins. In particular, EAOC of nitroolefins to provide 1,2,3-triazoles was realized in presence of various catalysts such as TBAF [15], $p$-toluene sulfonic acid [16], cerium triflate [17], and $\mathrm{Bi}_{2} \mathrm{WO}_{6}$ nanoparticles [18]. An alternative route of EAOC was realized by generating the nitroolefin in situ $[19,20]$. In previous decades, EAOC reaction of nitroolefins in the absence of catalysis required prolonged times for completion and resulted in low regioselectivity, and poor efficiency [21].

Considering the importance of 1,2,3-triazoles and in continuation of our experience in catalysis [22-25], herein we report the application of $\mathrm{FeCl}_{3}$ in ionic liquid (ILs) as a reusable homogeneous catalyst system. To our knowledge, this is the first EAOC of nitroolefins by using iron catalyst in ionic liquid.

ILs have recently received a good deal of attention since classical organic reactions, including cycloadditions reactions, can be performed in these media with great advantages (yield and selectivity) as compared to conventional conditions [26-30]. Ionic liquids are distinguished by the advantages pertaining to these solvents, such as no measurable vapor pressure, easy solvent recover/recycle, and high solubility of the Lewis acids in these solvents [31-33].

Recently, among the plethora of Lewis acids reported in the literature, iron catalysts have been identified as important and effective catalysts in various organic reactions because of their low price, easy availability, sustainability, nontoxicity, and environmentally friendly characteristics [34-40].

In this paper, we investigated a number of catalyzed-EAOC reactions of nitroolefins in different ionic liquids and Lewis acids. Finally, we selected the [mpy]OTf $/ \mathrm{FeCl}_{3}$ system considering both the strong coordination of the $\mathrm{NO}_{2}$ group to the Fe-catalyst and the use of 1-methyl pyridinium trifluoromethanesulfonate ([mpy]OTf) as an ideal reaction medium due the strong stabilization of reaction intermediates. The major advantages of using this ionic liquid are the low cost and the easy one-step preparation through halide-free direct synthesis by adding methyl trifluoromethane sulfonate directly to dry pyridine. 


\section{Results}

To begin, we chose the cycloaddition reaction between $(E)$-nitrostyrene 1a and benzylazide 2a in the presence of both imidazolium-based and pyridinium-based ionic liquids and some Lewis acid catalysts as the model system to optimize the reaction conditions for an efficient synthesis of the product 3a (Table 1).

Table 1. Optimization of reaction conditions ${ }^{1}$.

\begin{tabular}{cccccc} 
& & & \\
\hline
\end{tabular}

${ }_{1}^{1}$ Reaction conditions: 2.0 eq. of $2 \mathbf{a}$ were used unless the reaction in entry 1 , in which 1.0 eq. of $2 \mathbf{a}$ was employed.

$210 \mathrm{~mol} \% \mathrm{FeCl}_{3}$.

In an initial experiment, the reaction was performed in 1-methyl pyridinium trifluoromethanesulfonate ([mpy]OTf) at $60{ }^{\circ} \mathrm{C}$ catalyzed by $20 \mathrm{~mol} \% \mathrm{FeCl}_{3}$ in a $1: 1$ ratio of reagents, isolating 1,5-disubstituted triazole $3 \mathrm{a}$ in $24 \%$ yield after 48 -h reaction due to degradation of benzylazide 2a (Table 1, entry 1). The use of 1.2 eq. or 1.5 eq. of azide at $100{ }^{\circ} \mathrm{C}$ did not lead to satisfactory results. A doubling of azide concentration revealed an increase of yield to $40 \%$ (Table 1 , entry 2). Subsequently, when the reaction temperature was raised to $100{ }^{\circ} \mathrm{C}$, the yield of the product improved significantly, also reducing the reaction time (Table 1, entry 3). Any attempt to reduce the amount of catalyst did not provide improvements of the product yield (Table 1, entry 4).

Further screening of Lewis acids (Table 1, entries 5-8) revealed that the optimal results were obtained in the presence of $\mathrm{FeCl}_{3}$ as catalyst (Table 1, entry 3). Moreover, without any catalyst, the reagents $\mathbf{1 a}$ and $\mathbf{2 a}$ in same reaction conditions gave the 1,5-disubstituted triazole $\mathbf{3} \mathbf{a}$ in very low yield after a long reaction time (Table 1, entry 9). This last result highlights that the catalyst accelerates the reaction by increasing the electrophilicity of the nitroolefin through coordination, but it is not involved in the elimination step.

The changing from 1-methyl pyridinium trifluoromethane sulfonate [mpy]OTf to 1-butyl-3-methylimidazolium triflate [bmim]OTf, 1-butyl-3-methylimidazolium chloride [bmim] $\mathrm{Cl}$, or 1-butyl-3-methylimidazolium tetrafluoroborate [bmim] $\mathrm{BF}_{4}$ as solvent (Table 1, entries 10-12) did not have a significant influence on the outcome, and only minor differences in product yield were observed.

With the optimized reaction conditions in our hand, we extended the investigation to various arylnitroolefins $\mathbf{1} \mathbf{a}-\mathbf{n}$ and benzylazide $\mathbf{2} \mathbf{a}$ or phenylazide $\mathbf{2} \mathbf{b}$ (Table 2). 
Table 2. Synthesis of 1,5-disubstituted 1,2,3-triazoles 3a-n.

\begin{tabular}{|c|c|c|c|c|}
\hline & & & & $3 a-n$ \\
\hline Entry & $\mathbf{R}$ & $\mathbf{R}^{\prime}$ & Product & Yield (\%) \\
\hline 1 & $\mathrm{H}$ & $\mathrm{Bn}$ & $3 a$ & 95 \\
\hline 2 & $2-\mathrm{Cl}$ & $\mathrm{Bn}$ & $3 b$ & 85 \\
\hline 3 & $3-\mathrm{Cl}$ & $\mathrm{Bn}$ & $3 c$ & 84 \\
\hline 4 & $4-\mathrm{Cl}$ & $\mathrm{Bn}$ & $3 d$ & 86 \\
\hline 5 & 4-Me & $\mathrm{Bn}$ & $3 e$ & 92 \\
\hline 6 & $4-\mathrm{MeO}$ & $\mathrm{Bn}$ & $3 f$ & 93 \\
\hline 7 & $2-\mathrm{NO}_{2}$ & $\mathrm{Bn}$ & $3 g$ & 81 \\
\hline 8 & $\mathrm{H}$ & $\mathrm{Ph}$ & $3 \mathrm{~h}$ & 91 \\
\hline 9 & $2-\mathrm{Cl}$ & $\mathrm{Ph}$ & $3 \mathbf{i}$ & 87 \\
\hline 10 & $3-\mathrm{Cl}$ & $\mathrm{Ph}$ & $3 \mathbf{j}$ & 93 \\
\hline 11 & $4-\mathrm{Cl}$ & $\mathrm{Ph}$ & $3 k$ & 92 \\
\hline 12 & $4-\mathrm{Me}$ & $\mathrm{Ph}$ & 31 & 96 \\
\hline 13 & $4-\mathrm{MeO}$ & $\mathrm{Ph}$ & $3 m$ & 92 \\
\hline 14 & $2-\mathrm{NO}_{2}$ & $\mathrm{Ph}$ & $3 n$ & 95 \\
\hline
\end{tabular}

Notably, several sensitive functionalities, such as chloro (3b-d; $\mathbf{3} \mathbf{j}-\mathbf{k})$, methyl (3e; $\mathbf{3 l})$, methoxy (3f; $\mathbf{3 m})$, and nitro $(3 \mathrm{~g} ; 3 \mathrm{n})$, were unaffected under the present reaction conditions, and the reaction also tolerated ortho-substitution in the aromatic ring.

\section{Discussion}

In order to confirm the eliminative azide-olefin cycloaddition (EAOC) mechanism, we investigated the possible reaction pathway.

To gain deeper insight into the mechanism, the reaction was studied at the B3LYP-D3BJ/Def2SVP level of theory to calculate geometries and then single point calculations at the B3LYP-D3BJ/Def2TZVP level of theory were performed (for details, see Supplementary Materials). We studied as a model the reaction between phenyl azide PA and $(E)$-nitrostyrene NS to give compound $3 \mathbf{h}$. Initially, we calculated the direct cycloaddition between PA and NS without any catalyst to give the two intermediate cycloadducts. We considered two channels corresponding to the obtention of 1,4-(channel 1) and 1,5-adducts (channel 2). Two different relative orientations between the nitroolefin and the azide (endo/exo) were taken into account, thus having a total of four initial approaches (Scheme 2). The different approaches for each regioisomer actually lead to different isomers connected by a pyramidal inversion at the azide nitrogen. 

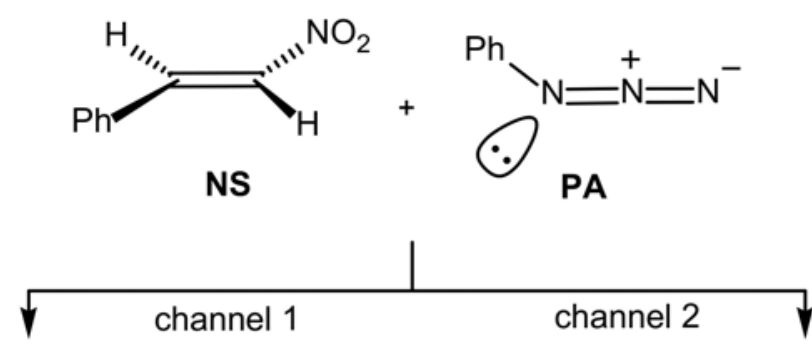

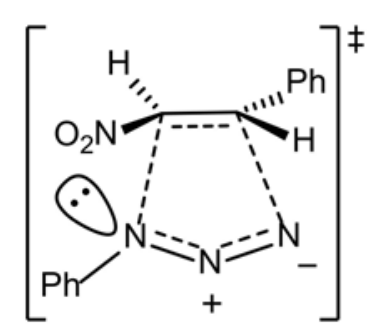

TS1x

(exo)

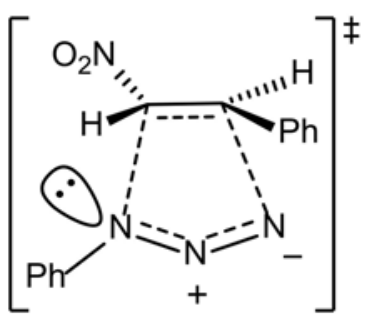

TS1n

(endo)<smiles>O=[N+]([O-])[C@@H]1[C@H](c2ccccc2)N=NN1c1ccccc1</smiles>

P14

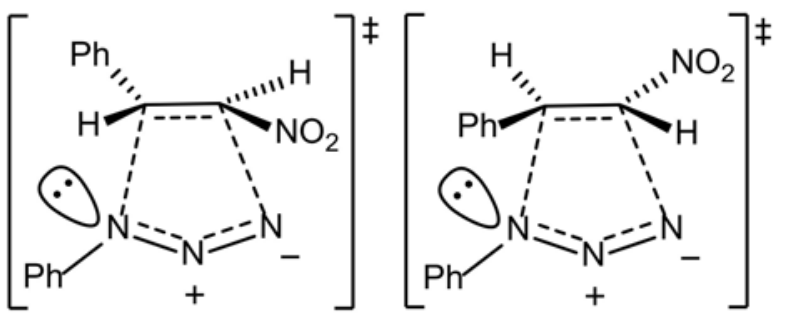

TS2x

(exo)
TS2n

(endo)<smiles>O=[N+]([O-])C1N=NN(c2ccccc2)[C@H]1c1ccccc1</smiles>

Scheme 2. Approaches for the cycloaddition between NS and PA.

The analysis of the optimized transition structures and the corresponding IRCs revealed concerted processes in all cases. The preferred one, TS2x, corresponded to channel 2/exo (energy barrier of $29.3 \mathrm{kcal} / \mathrm{mol}$ ), with differences of $0.2,2.1$, and $2.3 \mathrm{kcal} / \mathrm{mol}$ with respect to channel 2/endo (TS2n), channel 1/endo (TS1n), and channel 1/exo (TS1x), respectively (Scheme 2). Next, we evaluated the same reaction catalyzed by iron(III) chloride, which is coordinated at the nitro group. The same trend was observed for the catalyzed reaction. In the presence of iron(III) chloride, the barrier was reduced to $23.6 \mathrm{kcal} / \mathrm{mol}$ (Figure 1).

Denitration reaction is a well-known process that takes place through the thermal elimination of nitrous acid. The electronic nature of the reaction resembles a typical Cope elimination. Accordingly, a previous de-coordination is required to form P15. A barrier of $22.5 \mathrm{kcal} / \mathrm{mol}$ was found, the formation of the final product $3 \mathrm{~h}$ being thermodynamically favored by $25 \mathrm{kcal} / \mathrm{mol}$ (Figure 1). Consequently, for the iron-catalyzed process, the cycloaddition step is the rate-limiting one and it should be expected that the observed product of the reaction is $3 \mathrm{~h}$ in agreement with experimental observations. 


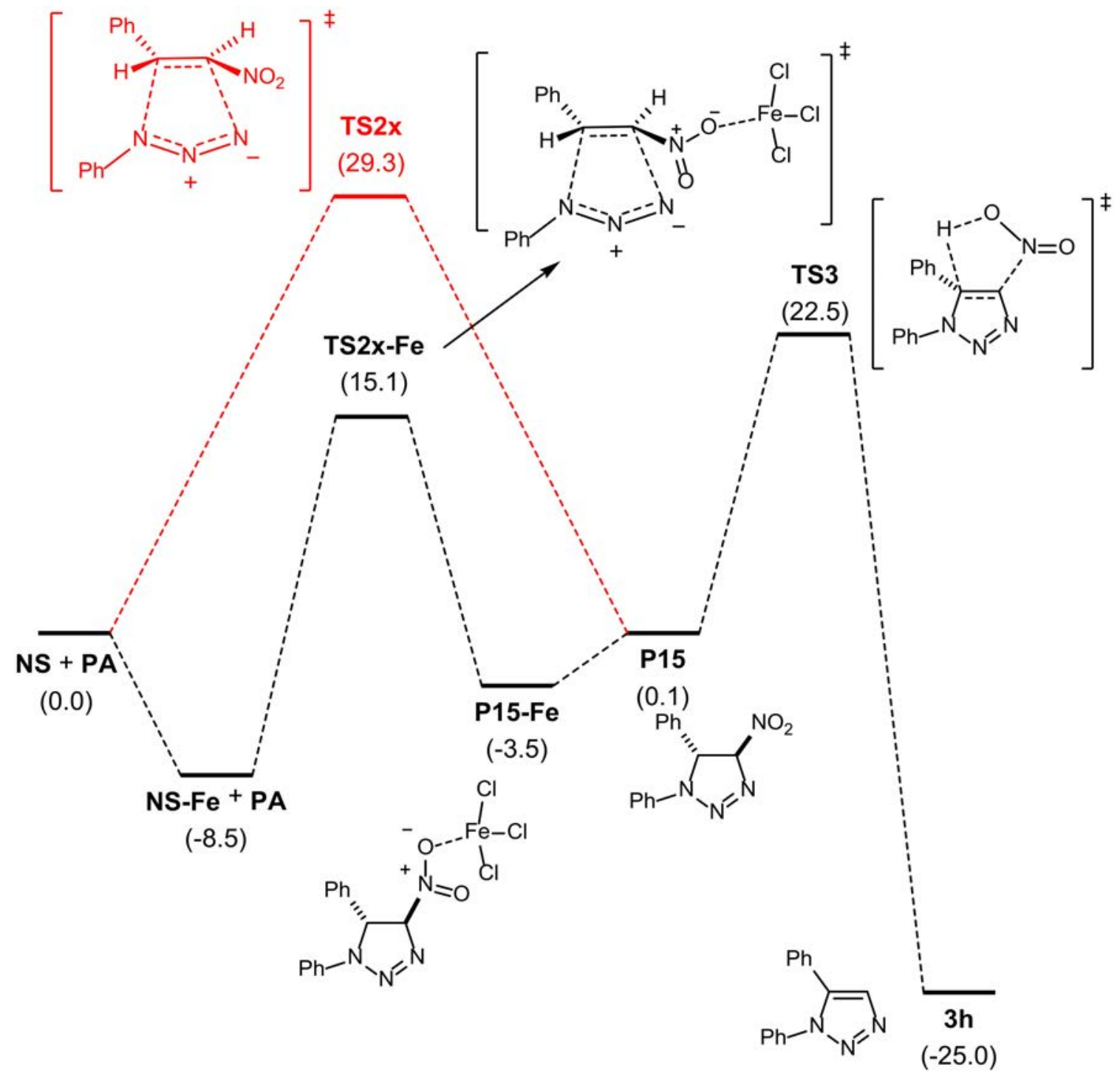

Figure 1. Reaction coordinate for the formation of $3 \mathrm{~h}$ from (E)-nitrostyrene and phenyl azide. Both catalyzed (iron(III) chloride) and uncatalyzed (in red) cycloaddition reactions are included for the purpose of comparison. (For detailed data, see Supplementary Materials).

The geometries of TS2x-Fe and TS3 are shown in Figure 2. The geometry of the former reflects the higher asynchronicity of the catalyzed cycloaddition, in which the N1-C5 bond of the triazoline is formed earlier that the N3-C4 bond.

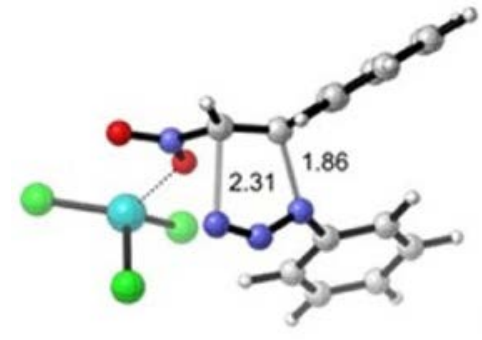

$\mathrm{TS} 2 \mathrm{x}-\mathrm{Fe}$

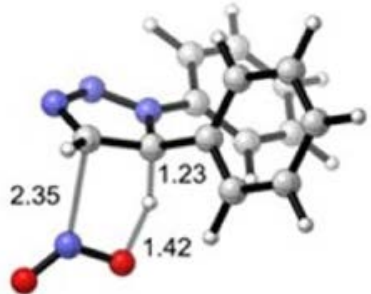

TS3

Figure 2. Optimized geometries (B3LYP-D3BJ/Def2SVP) of TS2 $x-F e$ and TS3. 
According to these findings, it is possible to propose the catalytic cycle illustrated in Scheme 3. The first step of the reaction is the coordination of iron(III) chloride to nitroolefin compound NS to form an activated intermediate NS-Fe that reacts with the azide derivative PA to produce a triazoline intermediate P15-Fe through a transition state TS2n-Fe. The final step consists of the production of $\mathrm{FeCl}_{3}$ in its original quantity and elimination of $\mathrm{HNO}_{2}$ to afford the 1,5-disubstituted 1,2,3-triazole $3 \mathbf{h}$ via a transition state TS3.<smiles>[R]n1nncc1-c1ccccc1</smiles>

$3 \mathrm{~h}$

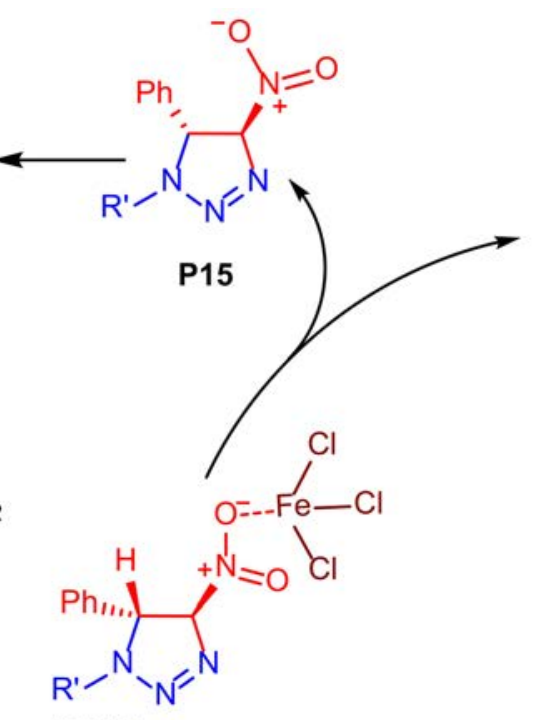<smiles>CC(C)(C)C1CCCCC1C=Cc1ccccc1</smiles><smiles>O=[N+](/C=C/c1ccccc1)OP(Cl)(Cl)(Cl)Cl</smiles>

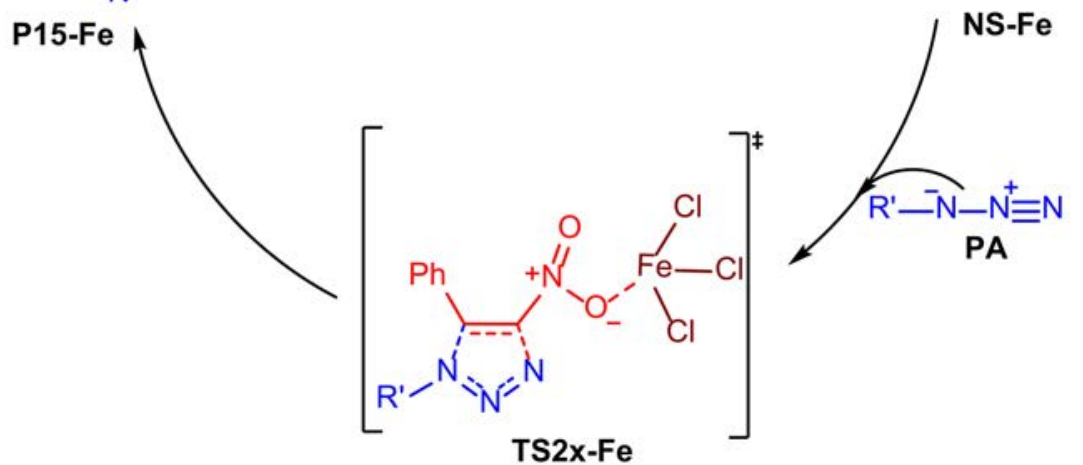

Scheme 3. Proposed mechanism of EAOC reaction.

Moreover, considering that the used ionic liquid ([mpy]OTf) was an excellent reaction medium, we suppose that this IL may stabilize the coordinated intermediates by general electrostatic interactions [28,41-43], favoring both the cycloaddition reaction with azide compound and the transformation of triazoline derivative in triazole substrate. In fact, the weak interaction between 1-methyl pyridinium cation and trifluoromethanesulfonate anion due to their dimension favors the possibility for the cation (or anion) to solvate the transition state (ionic coordinated intermediate) $[44,45]$.

The catalytic system IL/ $/ \mathrm{FeCl}_{3}$ has been analyzed also with respect to recovery and reuse in the reaction between $(E)$-nitrostyrene $\mathbf{1 a}$ and benzylazide $\mathbf{2 a}$ and the results are shown in Figure 3. 


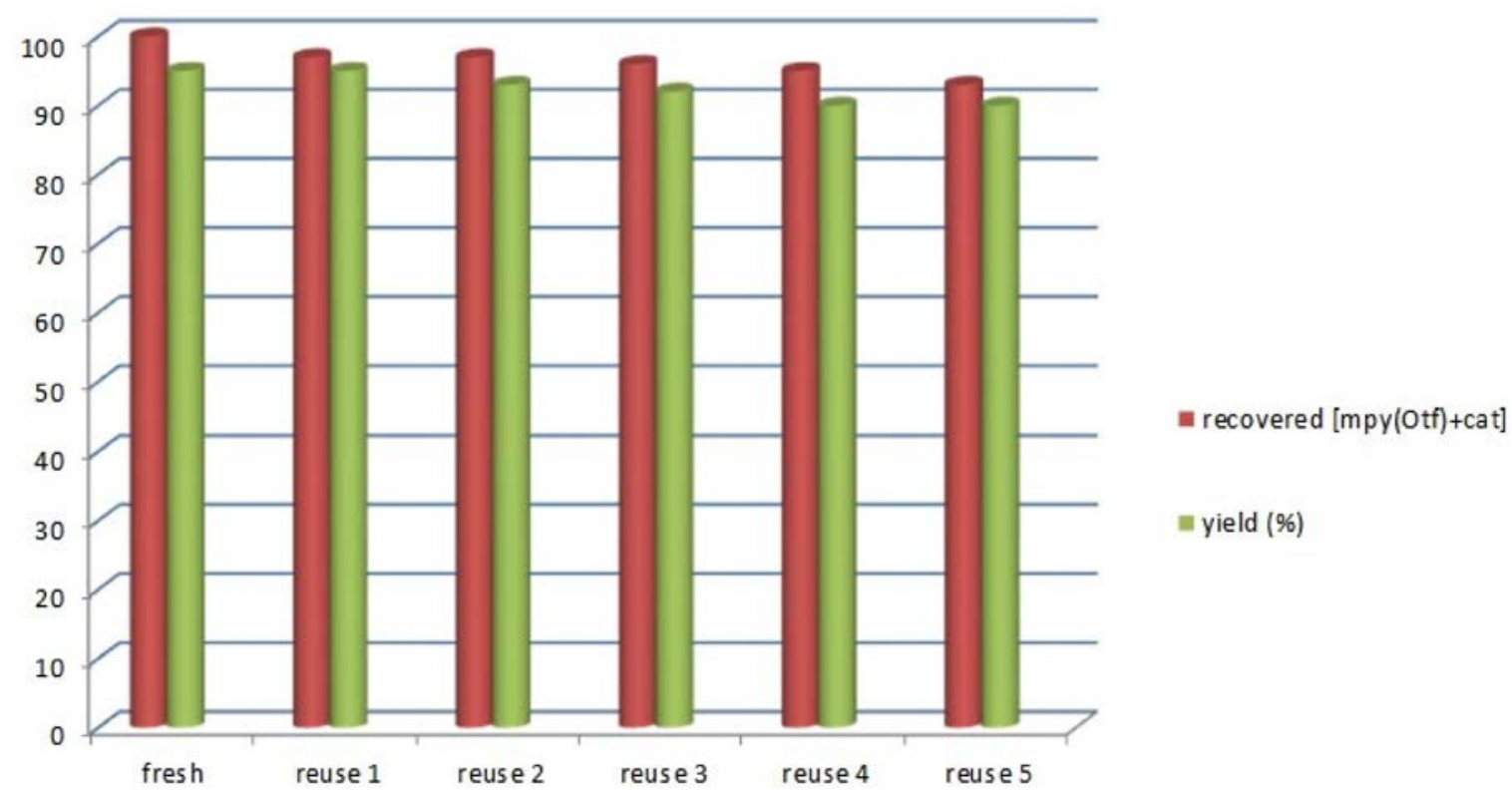

Figure 3. Recovery and re-use of catalytic $\mathrm{IL} / \mathrm{FeCl}_{3}$ system until six cycles.

As shown in Figure 3, similar conversions were obtained, showing that the ionic liquid $/ \mathrm{FeCl}_{3}$ system remains active until six cycles and that it can be recovered efficiently in this way.

\section{Materials and Methods}

All reagents and commercial ionic liquids were purchased from Sigma-Aldrich (St. Gallen, Switzerland) or Alfa Aesar (Karlsruhe, Germany) and used without purification. Reactions were monitored by TLC using silica plates 60-F264 commercially available from Merck (Darmstadt, Germany). ${ }^{1} \mathrm{H}$ and ${ }^{13} \mathrm{C}$ NMR spectra were recorded at 300 and $75 \mathrm{MHz}$, respectively, in $\mathrm{CDCl}_{3}$ using tetramethylsilane (TMS) as the internal standard (Bruker (Billerica, MA, USA) ACP $300 \mathrm{MHz}$ ). Chemical shifts are given in parts per million and coupling constants in Hertz. LC-MS analyses were carried using an Agilent 6540 UHD Accurate-Mass Q-TOF LC-MS (Agilent, Santa Clara, CA, USA) fitted with a electrospray ionization source (Dual AJS ESI) operating in positive ion mode. Chromatographic separation was achieved using a C18 RP analytical column (Poroshell 120, SB-C18, $50 \times 2.1 \mathrm{~mm}, 2.7 \mathrm{~mm}$ ) at $30^{\circ} \mathrm{C}$ with an elution gradient from $5 \%$ to $95 \%$ of B over $13 \mathrm{~min}$, a being $\mathrm{H}_{2} \mathrm{O}(0.1 \% \mathrm{FA})$ and $\mathrm{B} \mathrm{CH}_{3} \mathrm{CN}(0.1 \% \mathrm{FA})$. Flow rate was $0.4 \mathrm{~mL} \mathrm{~min}^{-1}$.

\subsection{Synthesis of 1-Methyl Pyridinium Trifluoromethanesulfonate}

1-methyl pyridinium trifluoromethanesulfonate ([mpy]OTf) was prepared by halide-free direct synthesis as reported in literature [29,46,47].

\subsection{General Procedure for Synthesis of 1,5-Disubstituted-1,2,3-Triazoles 3a-n}

In a two-necked round bottom flask, equipped with bubble condenser and magnetic stir bar, ionic liquid (5 mL), $\mathrm{FeCl}_{3}(20 \mathrm{~mol} \%),(E)$-nitrostyrene $1 \mathbf{a}-\mathbf{n}(1 \mathrm{eq}$.$) , and azide \mathbf{2 a - b}(2 \mathrm{eq}$.$) were$ placed. The reaction was conducted at $100^{\circ} \mathrm{C}$ for the appropriate time. The crude was extracted with dichloromethane $(3 \times 5 \mathrm{~mL})$ and the combined organic layer was evaporated under vacuum. The crude product was purified on a flash silica gel column by using hexane/ethyl acetate $(9: 1 v / v)$ to obtain the desired product (3a-n). Complete characterization of all products is reported in Appendix A. 


\subsection{Procedure of Recycling of the Catalytic System IL/FeCl 3}

After the polar phase was extracted three times by dichloromethane, the ionic liquid $/ \mathrm{FeCl}_{3}$ mixture was washed with hexane and dried at $65^{\circ} \mathrm{C}$ under vacuum condition. Successive runs were performed in the recycled ionic liquid $/ \mathrm{FeCl}_{3}$ by reacting fresh reagents at the usual conditions.

\section{Conclusions}

In conclusion, we have reported an efficient approach to prepare 1,5-disubstitued-1,2,3-triazole derivatives via $\mathrm{FeCl}_{3}$-mediated eliminative azide-olefin cycloadditions (EAOC) in ionic liquid as a solvent. The principle features of this synthetic method are high atom economy, simple operation, high yields, and the reuse of catalytic system $\mathrm{IL} / \mathrm{FeCl}_{3}$ until six cycles. The nature of the Lewis acid and ionic liquid appears to have a large impact to the regiocontrol of the reaction, where the ionic liquid anion might stabilize the cationic transition state, allowing formation of the triazoline intermediate. Theoretical calculations indicate that an asynchronous concerted dipolar cycloaddition-elimination process might be involved in the formation of 1,5-functionalized triazoles. Moreover, they support the hypothesis that the subsequent elimination step to carry out triazoles proceeds without iron coordination.

Supplementary Materials: The following are available online at http://www.mdpi.com/2073-4344/8/9/364/s1, 1 . ${ }^{1} \mathrm{H}$ NMR, ${ }^{13} \mathrm{C}$ NMR, and ESI(+)-MS spectra. 2. Theoretical Calculations: Table S1: Absolute (hartrees) and relative $(\mathrm{kcal} / \mathrm{mol})$ energies (B3LYP-D3BJ/Def2TZVP/CPCM = water// B3LYPD3BJ/Def2SVP) corresponding to the reaction between NS and PA, Figure S1: Optimized geometries of transition structures, Table S2: Absolute (hartrees) and relative (kcal/mol) energies (B3LYP-D3BJ/Def2TZVP/CPCM = water// B3LYPD3BJ/Def2SVP) corresponding to the reaction between NS and PA catalyzed by $\mathrm{FeCl}_{3}$, Figure S2: Optimized geometries of transition structures, Table S3: Absolute (hartrees) and relative $(\mathrm{kcal} / \mathrm{mol})$ energies (B3LYP-D3BJ/Def2TZVP/CPCM = water// B3LYPD3BJ/Def2SVP) corresponding to the denitration of P15, Figure S3: Optimized geometry of transition structure. 3. Cartesian Coordinates.

Author Contributions: Conceptualization, A.D.N. and L.M.; Methodology, B.R., V.A., and M.A.T.; Software, P.M.; Validation, A.D.N., L.M., and P.M.; Formal Analysis, M.N. and M.L.D.G.; Investigation, P.M.; Data Curation, L.M., V.A.; Writing-Original Draft Preparation, A.D.N. and L.M.; Supervision, P.M. and A.D.N.

Acknowledgments: We thank the Italian Ministry of University and Scientific Research (MIUR) for a doctoral grant and the University of Calabria for financial support. This research was supported by the Spanish MINECO (FEDER-CTQ2016-76155-R to P.M.) The authors thankfully acknowledge the resources from the supercomputers "Memento" and "Cierzo", technical expertise and assistance provided by BIFI-ZCAM (Universidad de Zaragoza, Spain).

Conflicts of Interest: The authors declare no conflict of interest

\section{Appendix A}

\section{Data for the Products}

All products were characterized by ESI(+)-MS, ${ }^{1} \mathrm{H}$ and ${ }^{13} \mathrm{C}$ NMR. The regioisomery was attributed by comparison with literature data [17].

1-Benzyl-5-phenyl-1,2,3-triazole (3a). ${ }^{1} \mathrm{H}-\mathrm{NMR}\left(\mathrm{CDCl}_{3}, 300 \mathrm{MHz}\right): \delta$ (ppm) 5.55 (s, 2H, $\left.\mathrm{CH}_{2}\right), 7.05-7.12$ (m, 2H, Ar), 7.22-7.33 (m, 5H, Ar), 7.38-7.48 (m, 3H, Ar), 7.75 (s, 1H, CH). ${ }^{13} \mathrm{C}-\mathrm{NMR}\left(\mathrm{CDCl}_{3}, 75 \mathrm{MHz}\right)$ : $\delta$ (ppm) 51.83, 126.97, 127.17, 128.16, 128.82, 128.92, 128.95, 129.50, 133.30, 135.53, 138.15. ESI(+)-MS: $m / z[\mathrm{M}+\mathrm{H}]$ calcd for $\mathrm{C}_{15} \mathrm{H}_{14} \mathrm{~N}_{3} 236.1182$, found: 236.0952 .

1-Benzyl-5-(2-chlorophenyl)-1,2,3-triazole (3b). ${ }^{1} \mathrm{H}-\mathrm{NMR}\left(\mathrm{CDCl}_{3}, 300 \mathrm{MHz}\right): \delta(\mathrm{ppm}) 5.45$ (s, 2H, $\left.\mathrm{CH}_{2}\right)$, 6.90-6.99 (m, 2H, Ar), 7.01 (d, 1H, J = 7.60 Hz, 1.70 Hz, Ar), 7.15-7.30 (m, 4H, Ar), $7.40(\mathrm{td}, 1 \mathrm{H}$, $J=7.70 \mathrm{~Hz}, 1.70 \mathrm{~Hz}, \mathrm{Ar}), 7.47-7.52(\mathrm{~m}, 1 \mathrm{H}, \mathrm{Ar}), 7.72(\mathrm{~s}, 1 \mathrm{H}, \mathrm{CH}) .{ }^{13} \mathrm{C}-\mathrm{NMR}\left(\mathrm{CDCl}_{3}, 75 \mathrm{MHz}\right): \delta(\mathrm{ppm})$ 52.50, 126.44, 126.90, 127.72, 128.21, 128.62, 129.97, 131.18, 132.01, 134.32, 134.43, 134.78, 134.83. ESI(+)-MS: $m / z[\mathrm{M}+\mathrm{H}]$ calcd for $\mathrm{C}_{15} \mathrm{H}_{13} \mathrm{ClN}_{3} 270.0793$, found: 270.1254 . 
1-Benzyl-5-(3-chlorophenyl)-1,2,3-triazole (3c). ${ }^{1} \mathrm{H}-\mathrm{NMR}\left(\mathrm{CDCl}_{3}, 300 \mathrm{MHz}\right): \delta(\mathrm{ppm}) 5.55$ (s, 2H, $\left.\mathrm{CH}_{2}\right)$, 7.05-7.16 (m, 3H, Ar), 7.23 (m, 1H, Ar), 7.26-7.34 (m, 3H, Ar), 7.36 (d, 1H, J = 7.55 Hz, Ar), 7.39-7.45 $(\mathrm{m}, 1 \mathrm{H}, \mathrm{Ar}), 7.75(\mathrm{~s}, 1 \mathrm{H}, \mathrm{CH}) ;{ }^{13} \mathrm{C}-\mathrm{NMR}\left(\mathrm{CDCl}_{3}, 75 \mathrm{MHz}\right): \delta(\mathrm{ppm}) 52.11,127.03,127.21,128.37$, 128.64, 128.94, 129.01, 129.66, 130.22, 133.52, 134.92, 135.18, 136.80. ESI(+)-MS: $m / z$ [M + H] calcd for $\mathrm{C}_{15} \mathrm{H}_{13} \mathrm{ClN}_{3} 270.0793$, found: 270.1256 .

1-Benzyl-5-(4-chlorophenyl)-1,2,3-triazole (3d). ${ }^{1} \mathrm{H}$ NMR $\left(\mathrm{CDCl}_{3}, 300 \mathrm{MHz}\right): \delta(\mathrm{ppm}) 5.54\left(\mathrm{~s}, 2 \mathrm{H}, \mathrm{CH}_{2}\right)$, 7.03-7.10 (m, 2H, Ar), 7.14-7.21 (m, 2H, Ar), 7.25-7.33 (m, 3H, Ar), 7.36-7.43 (m, 2H, Ar), $7.74(\mathrm{~s}, 1 \mathrm{H}$, $\mathrm{CH}) ;{ }^{13} \mathrm{C} \mathrm{NMR}\left(\mathrm{CDCl}_{3}, 75 \mathrm{MHz}\right): \delta$ (ppm) 51.95, 125.37, 127.07, 128.31, 128.94, 129.26, 130.19, 133.46, 135.30, 135.85, 137.04. ESI(+)-MS: $m / z$ [M + H] calcd for $\mathrm{C}_{15} \mathrm{H}_{13} \mathrm{ClN}_{3} 270.0793$, found: 270.1252.

1-Benzyl-5-(4-methylphenyl)-1,2,3-triazole (3e). ${ }^{1} \mathrm{H}$ NMR $\left(\mathrm{CDCl}_{3}, 300 \mathrm{MHz}\right): \delta(\mathrm{ppm}) 2.43\left(\mathrm{~s}, 3 \mathrm{H}, \mathrm{CH}_{3}\right)$, $5.57\left(\mathrm{~s}, 2 \mathrm{H}, \mathrm{CH}_{2}\right), 7.09-7.22(\mathrm{~m}, 4 \mathrm{H}, \mathrm{Ar}), 7.22-7.29(\mathrm{~m}, 2 \mathrm{H}, \mathrm{Ar}), 7.29-7.37(\mathrm{~m}, 3 \mathrm{H}, \mathrm{Ar}), 7.75(\mathrm{~s}, 1 \mathrm{H}, \mathrm{CH})$; ${ }^{13} \mathrm{C} \mathrm{NMR}\left(\mathrm{CDCl}_{3}, 75 \mathrm{MHz}\right): \delta$ (ppm) 21.31, 51.71, 123.94, 128.10, 128.76, 128.81, 129.64, 133.16, 135.67, 139.63. ESI(+)-MS: $m / z[\mathrm{M}+\mathrm{H}]$ calcd for $\mathrm{C}_{16} \mathrm{H}_{16} \mathrm{~N}_{3} 250.1339$, found: 250.1241 .

1-Benzyl-5-(4-methoxyphenyl)-1,2,3-triazole (3f). ${ }^{1} \mathrm{H} \mathrm{NMR}\left(\mathrm{CDCl}_{3}, 300 \mathrm{MHz}\right): \delta(\mathrm{ppm}) 3.87\left(\mathrm{~s}, 3 \mathrm{H}, \mathrm{CH}_{3}\right)$, $5.56\left(\mathrm{~s}, 2 \mathrm{H}, \mathrm{CH}_{2}\right), 6.92-6.99(\mathrm{~m}, 2 \mathrm{H}, \mathrm{Ar}), 7.08-7.16(\mathrm{~m}, 2 \mathrm{H}, \mathrm{Ar}), 7.17-7.24(\mathrm{~m}, 2 \mathrm{H}, \mathrm{Ar}), 7.28-7.37(\mathrm{~m}, 3 \mathrm{H}$, $\mathrm{Ar}), 7.73$ (s, $1 \mathrm{H}, \mathrm{CH}) ;{ }^{13} \mathrm{C} \mathrm{NMR}\left(\mathrm{CDCl}_{3}, 75 \mathrm{MHz}\right): \delta$ (ppm) 51.67, 55.39, 114.42, 119.01, 127.12, 128.12, 128.84, 130.25, 133.09, 135.69, 137.99, 160.52. ESI(+)-MS: $m / z$ [M + H] calcd for $\mathrm{C}_{16} \mathrm{H}_{16} \mathrm{~N}_{3} \mathrm{O} 266.1288$, found: 266.1609 .

1-Benzyl-5-(2-nitrophenyl)-1,2,3-triazole (3g). ${ }^{1} \mathrm{H}$ NMR ( $\left.\mathrm{CDCl}_{3}, 300 \mathrm{MHz}\right): \delta(\mathrm{ppm}) 5.42\left(\mathrm{~s}, 2 \mathrm{H}, \mathrm{CH}_{2}\right)$, 6.90-6.97 (m, 2H, Ar), $7.00(\mathrm{dd}, 1 \mathrm{H}, J=7.50 \mathrm{~Hz}, 1.53 \mathrm{~Hz}, \mathrm{Ar}), 7.15-7.25(\mathrm{~m}, 3 \mathrm{H}, \mathrm{Ar}), 7.55(\mathrm{td}, 1 \mathrm{H}$, $J=7.54 \mathrm{~Hz}, 1.56 \mathrm{~Hz}, \mathrm{Ar}), 7.62(\mathrm{dd}, 1 \mathrm{H}, J=7.95 \mathrm{~Hz}, 1.56 \mathrm{~Hz}, \mathrm{Ar}), 7.66(\mathrm{~s}, 1 \mathrm{H}, \mathrm{CH}), 8.12(\mathrm{dd}, 1 \mathrm{H}$, $J=8.21 \mathrm{~Hz}, 1.43 \mathrm{~Hz}, \mathrm{Ar}) ;{ }^{13} \mathrm{C} \mathrm{NMR}\left(\mathrm{CDCl}_{3}, 75 \mathrm{MHz}\right): \delta(\mathrm{ppm}) 52.85,122.27,124.92,127.77,128.42$, 128.72, 131.01, 133.04, 133.11, 133.23, 133.94, 134.40. ESI(+)-MS: $m / z[\mathrm{M}+\mathrm{H}]$ calcd for $\mathrm{C}_{15} \mathrm{H}_{13} \mathrm{~N}_{4} \mathrm{O}_{2}$ 281.1033, found: 281.1016 .

1,5-Diphenyl-1,2,3-triazole (3h). ${ }^{1} \mathrm{H}$ NMR ( $\left.\mathrm{CDCl}_{3}, 300 \mathrm{MHz}\right): \delta$ (ppm) 7.22-7.31 (m, 2H, Ar), 7.36-7.44

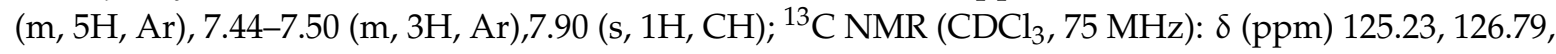
$128.61,128.87,129.24,129.37,133.41,136.64,137.75$. ESI(+)-MS: $m / z[\mathrm{M}+\mathrm{H}]$ calcd for $\mathrm{C}_{14} \mathrm{H}_{12} \mathrm{~N}_{3}$ 222.1026, found: 222.0591 .

5-(2-Chlorophenyl)-1-phenyl-1,2,3-triazole (3i). ${ }^{1} \mathrm{H}$ NMR ( $\left.\mathrm{CDCl}_{3}, 300 \mathrm{MHz}\right): \delta(\mathrm{ppm}) 7.22-7.32(\mathrm{~m}, 2 \mathrm{H}$,

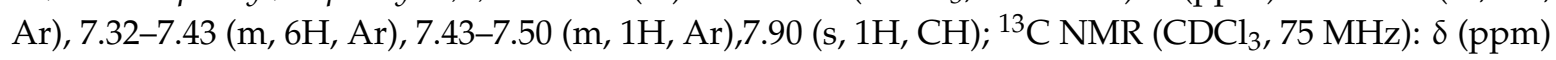
124.16, 126.60, 127.02, 129.02, 129.26, 130.22, 131.07, 131.95, 134.13, 134.75, 134.90, 136.62. ESI(+)-MS: $m / z[\mathrm{M}+\mathrm{H}]$ calcd for $\mathrm{C}_{14} \mathrm{H}_{11} \mathrm{ClN}_{3} 256.0636$, found: 256.0782 .

5-(3-Chlorophenyl)-1-phenyl-1,2,3-triazole (3j). ${ }^{1} \mathrm{H}$ NMR $\left(\mathrm{CDCl}_{3}, 300 \mathrm{MHz}\right): \delta(\mathrm{ppm})$ 7.06-7.13 (m, 1H, $\mathrm{Ar}), 7.26-7.35$ (m, 2H, Ar), 7.35-7.44 (m, 3H, Ar), 7.45-7.55 (m, 3H, Ar), 7.92 (s, 1H, CH); ${ }^{13} \mathrm{C}$ NMR $\left(\mathrm{CDCl}_{3}, 75 \mathrm{MHz}\right): \delta$ (ppm) 125.21, 126.73, 128.57, 129.39, 129.53, 129.55, 130.14, 133.64, 134.89, 136.28, 136.42. ESI(+)-MS: $m / z$ [M + H] calcd for $\mathrm{C}_{14} \mathrm{H}_{11} \mathrm{ClN}_{3} 256.0636$, found: 256.0781 .

5-(4-Chlorophenyl)-1-phenyl-1,2,3-triazole (3k). ${ }^{1} \mathrm{H}$ NMR $\left(\mathrm{CDCl}_{3}, 300 \mathrm{MHz}\right): \delta(\mathrm{ppm}) 7.13-7.20(\mathrm{~m}, 2 \mathrm{H}$, $\mathrm{Ar}), 7.30-7.39$ (m, 4H, Ar), 7.43-7.50 (m, 3H, Ar),7.87 (s, 1H, CH); $\left.{ }^{13} \mathrm{C} \mathrm{NMR} \mathrm{(CDCl} 3,75 \mathrm{MHz}\right): \delta$ (ppm) $125.23,129.23,129.47,129.52,129.83,133.45,135.51,136.38,136.68$. ESI(+)-MS: $m / z$ [M + H] calcd for $\mathrm{C}_{14} \mathrm{H}_{11} \mathrm{ClN}_{3} 256.0636$, found: 256.0781 .

5-(4-Methylphenyl)-1-phenyl-1,2,3-triazole (31). ${ }^{1} \mathrm{H}$ NMR $\left(\mathrm{CDCl}_{3}, 300 \mathrm{MHz}\right): \delta(\mathrm{ppm}) 2.36\left(\mathrm{~s}, 3 \mathrm{H}, \mathrm{CH}_{3}\right)$, 7.08-7.18 (m, 4H, Ar), 7.33-7.41 (m, 2H, Ar), 7.41-7.48 (m, 3H, Ar),7.84 (s, 1H, CH); ${ }^{13} \mathrm{C} \mathrm{NMR}\left(\mathrm{CDCl}_{3}\right.$, $75 \mathrm{MHz}): \delta$ (ppm) 21.30, 116.82, 123.74, 125.25, 128.47, 129.21, 129.58, 133.14, 137.89, 139.42. ESI(+)-MS: $m / z[\mathrm{M}+\mathrm{H}]$ calcd for $\mathrm{C}_{15} \mathrm{H}_{14} \mathrm{~N}_{3} 236.1182$, found: 236.0834 .

5-(4-Methoxyphenyl)-1-phenyl-1,2,3-triazole (3m). ${ }^{1} \mathrm{H}$ NMR ( $\left.\mathrm{CDCl}_{3}, 300 \mathrm{MHz}\right): \delta(\mathrm{ppm}) 3.81$ (s, 3H, $\left.\mathrm{CH}_{3}\right)$, 6.83-6.90 (m, 2H, Ar), 7.10-7.18 (m, 2H, Ar), 7.34-7.41 (m, 2H, Ar),7.41-7.48 (m, 3H, Ar), 7.81 (s, 1H, 
$\mathrm{CH}) ;{ }^{13} \mathrm{C} \mathrm{NMR}\left(\mathrm{CDCl}_{3}, 75 \mathrm{MHz}\right): \delta$ (ppm) 55.32, 114.35, 118.95, 125.24, 129.14, 129.35, 129.96, 132.96, 136.76, 137.60, 160.28. ESI(+)-MS: $m / z$ [M + H] calcd for $\mathrm{C}_{15} \mathrm{H}_{14} \mathrm{~N}_{3} \mathrm{O} 252.1131$, found: 252.1197.

5-(2-Nitrophenyl)-1-phenyl-1,2,3-triazole (3n). ${ }^{1} \mathrm{H}$ NMR $\left(\mathrm{CDCl}_{3}, 300 \mathrm{MHz}\right): \delta(\mathrm{ppm}) 7.28-7.31(\mathrm{~m}, 1 \mathrm{H}$, Ar), 7.33-7.42 (m, 3H, Ar), 7.46 (dd, 1H, $J=7.42 \mathrm{~Hz}, 1.70 \mathrm{~Hz}, \mathrm{Ar}), 7.60-7.75(\mathrm{~m}, 3 \mathrm{H}, \mathrm{Ar}), 7.84(\mathrm{~s}, 1 \mathrm{H}$, $\mathrm{CH}), 8.04(\mathrm{dd}, 1 \mathrm{H}, J=7.90 \mathrm{~Hz}, 1.60 \mathrm{~Hz}, \mathrm{Ar}) ;{ }^{13} \mathrm{C} \mathrm{NMR}\left(\mathrm{CDCl}_{3}, 75 \mathrm{MHz}\right): \delta(\mathrm{ppm}) 122.56,124.53$, $125.17,129.38,129.46,130.92,132.78,133.45,133.75,135.94,148.34$. ESI(+)-MS: $m / z$ [M + H] calcd for $\mathrm{C}_{14} \mathrm{H}_{11} \mathrm{~N}_{4} \mathrm{O}_{2}$ 267.0877, found: 267.1267.

\section{References}

1. Angell, Y.L.; Burgess, K. Peptidomimetics via copper-catalyzed azide-alkyne cycloadditions. Chem. Soc. Rev. 2007, 36, 1674-1689. [CrossRef] [PubMed]

2. Singhal, N.; Sharma, P.K.; Dudhe, R.; Kumar, N. Recent advancement of triazole derivatives and their biological significance. J. Chem. Pharm. Res. 2011, 3, 126-133.

3. Tron, G.C.; Pirali, T.; Billington, R.A.; Canonico, P.L.; Sorba, G.; Genazzani, A.A. Click chemistry reactions in medicinal chemistry: Applications of the 1,3-dipolar cycloaddition between azides and alkynes. Med. Res. Rev. 2008, 28, 278-308. [CrossRef] [PubMed]

4. Thirumurugan, P.; Matosiuk, D.; Jozwiak, K. Click Chemistry for Drug Development and Diverse Chemical-Biology Applications. Chem. Rev. 2013, 113, 4905-4979. [CrossRef] [PubMed]

5. Ali, A.A.; Gogoi, D.; Chaliha, A.K.; Buragohain, A.K.; Trivedi, P.; Saikia, P.J.; Gehlot, P.S.; Kumar, A.; Chaturvedi, V.; Sarma, D. Synthesis and biological evaluation of novel 1,2,3-triazole derivatives as anti-tubercular agents. Bioorg. Med. Chem. Lett. 2017, 27, 3698-3703.

6. Huisgen, R. 1,3-dipolar cycloadditions. Paste and future. Angew. Chem. Int. Ed. Engl. 1963, 2, 565-598. [CrossRef]

7. Tornøe, C.W.; Christensen, C.; Meldal, M. Peptidotriazoles on Solid Phase: [1,2,3]-Triazoles by Regiospecific Copper(I)-Catalyzed 1,3-Dipolar Cycloadditions of Terminal Alkynes to Azides. J. Org. Chem. 2002, 67, 3057-3064. [CrossRef] [PubMed]

8. Rostovtsev, V.V.; Green, L.G.; Fokin, V.V.; Sharpless, K.B. A Stepwise Huisgen Cycloaddition Process: Copper(I)-Catalyzed Regioselective Ligation of Azides and Terminal Alkynes. Angew. Chem. Int. Ed. 2002, 41, 2596-2599. [CrossRef]

9. Zhang, L.; Chen, X.; Xue, P.; Sun, H.H.Y.; Williams, I.D.; Sharpless, K.B.; Fokin, V.V.; Jia, G. Ruthenium-Catalyzed Cycloaddition of Alkynes and Organic Azides. J. Am. Chem. Soc. 2005, 127, 15998-15999. [CrossRef] [PubMed]

10. Rasmussen, L.K.; Boren, B.C.; Fokin, V.V. Ruthenium-Catalyzed Cycloaddition of Aryl Azides and Alkynes. Org. Lett. 2007, 9, 5337-5339. [CrossRef] [PubMed]

11. Boren, B.C.; Narayan, S.; Rasmussen, L.K.; Zhang, L.; Zhao, H.; Lin, Z.; Jia, G.; Fokin, V.V. Ruthenium-Catalyzed Azide-Alkyne Cycloaddition: Scope and Mechanism. J. Am. Chem. Soc. 2008, 130, 8923-8930. [CrossRef] [PubMed]

12. Huisgen, R.; Szeimies, G.; Möbius, L. Azide Chemistry—An Inorganic Perspective [3 + 2]-Cycloaddition Reactions of Metal Azides and Related Systems. Chem. Ber. 1966, 99, 475-490. [CrossRef]

13. Broeckx, W.; Overbergh, N.; Samyn, C.; Smets, G.; Labbe, G. Cycloaddition reactions of azides with electron-poor olefins: Isomerization and thermolysis of the resulting $\Delta^{2}$-triazolines. Tetrahedron 1971, 27, 3527-3534. [CrossRef]

14. Gangaprasad, D.; Raj, J.P.; Kiranmye, T.; Sasikala, R.; Karthikeyan, K.; Rani, S.K.; Elangovan, J. A tunable route to oxidative and eliminative [3+2] cycloadditions of organic azides with nitroolefins: $\mathrm{CuO}$ nanoparticles catalyzed synthesis of 1,2,3-triazoles under solvent-free condition. Tetrahedron Lett. 2016, 57, 3105-3108. [CrossRef]

15. Amantini, D.; Fringuelli, F.; Piermatti, O.; Pizzo, F.; Zunino, E.; Vaccaro, L. Synthesis of 4-Aryl-1H-1,2,3-triazoles through TBAF-Catalyzed [3 + 2] Cycloaddition of 2-Aryl-1-nitroethenes with $\mathrm{TMSN}_{3}$ under Solvent-Free Conditions. J. Org. Chem. 2005, 70, 6526-6529. [CrossRef] [PubMed]

16. Quan, X.-J.; Ren, Z.-H.; Wang, Y.-Y.; Guan, Z.-H. p-Toluenesulfonic Acid Mediated 1,3-Dipolar Cycloaddition of Nitroolefins with $\mathrm{NaN}_{3}$ for Synthesis of 4-Aryl-NH-1,2,3-triazoles. Org. Lett. 2014, 16, 5728-5731. [CrossRef] [PubMed] 
17. Wang, Y.-C.; Xie, Y.-Y.; Qu, H.-E.; Wang, H.-S.; Pan, Y.-M.; Huang, F.-P. Ce(OTf $)_{3}$-Catalyzed [3 + 2] Cycloaddition of Azides with Nitroolefins: Regioselective Synthesis of 1,5-Disubstituted 1,2,3-Triazoles. J. Org. Chem. 2014, 79, 4463-4464. [CrossRef] [PubMed]

18. Paplal, B.; Nagaraju, S.; Palakollu, V.; Kanvah, S.; Kumar, B.V.; Kashinath, D. Synthesis of functionalized 1,2,3-triazoles using $\mathrm{Bi}_{2} \mathrm{WO}_{6}$ nanoparticles as efficient and reusable heterogeneous catalyst in aqueous medium. RSC Adv. 2015, 5, 57842-57846. [CrossRef]

19. Sengupta, S.; Duan, H.; Lu, W.; Petersen, J.L.; Shi, X. One Step Cascade Synthesis of 4,5-Disubstituted-1,2,3-(NH)-Triazoles. Org. Lett. 2008, 10, 1493-1496. [CrossRef] [PubMed]

20. Thomas, J.; John, J.; Parekh, N.; Dehaen, W. A metal-free three-component reaction for the regioselective synthesis of 1,4,5-trisubstituted 1,2,3-triazoles. Angew. Chem. Int. Ed. 2014, 53, 10155-10159. [CrossRef] [PubMed]

21. Zefirov, N.S.; Chapovskaya, N.K.; Kolesnikov, V.V. Synthesis of 1,2,3-triazoles by reaction of azide ion with $\alpha \beta$-unsaturated nitro-compounds and nitriles. Chem. Commun. 1971, 17, 1001-1002. [CrossRef]

22. De Nino, A.; Bortolini, O.; Maiuolo, L.; Garofalo, A.; Russo, B.; Sindona, G. A sustainable procedure for highly enantioselective organocatalyzed Diels-Alder cycloadditions in homogeneous ionic liquid/water phase. Tetrahedron Lett. 2011, 52, 1415-1417. [CrossRef]

23. Nardi, M.; Di Gioia, M.L.; Costanzo, P.; De Nino, A.; Maiuolo, L.; Oliverio, M.; Olivito, F.; Procopio, A. Selective Acetylation of Small Biomolecules and Their Derivatives Catalyzed by Er(OTf $)_{3}$. Catalysts 2017, 7, 269-281. [CrossRef]

24. Di Gioia, M.L.; Costanzo, P.; De Nino, A.; Maiuolo, L.; Nardi, M.; Olivito, F.; Procopio, A. Simple and efficient Fmoc removal in ionic liquid. RSC Adv. 2017, 7, 36482-36491. [CrossRef]

25. Nardi, M.; Cano, N.H.; De Nino, A.; Di Gioia, M.L.; Maiuolo, L.; Oliverio, M.; Santiago, A.; Sorrentino, D.; Procopio, A. An eco-friendly tandem tosylation/Ferrier $N$-glycosylation of amines catalyzed by $\operatorname{Er}(\mathrm{OTf})_{3}$ in 2-MeTHF. Tetrahedron Lett. 2017, 58, 1721-1726. [CrossRef]

26. Padar, P.; Bokros, A.; Paragi, G.; Forgo, P.; Kele, Z.; Howarth, N.M.; Kovacs, L. Single Diastereomers of Polyhydroxylated 9-Oxa-1-azabicyclo[4.2.1]nonanes from Intramolecular 1,3-Dipolar Cycloaddition of w-Unsaturated Nitrones. J. Org. Chem. 2006, 71, 8669-8672. [CrossRef] [PubMed]

27. Rodriquez, M.; Sega, A.; Taddei, M. Ionic Liquid as a Suitable Phase for Multistep Parallel Synthesis of an Array of Isoxazolines. Org. Lett. 2003, 5, 4029-4031. [CrossRef] [PubMed]

28. Aggarwal, A.; Lancaster, N.L.; Sethi, A.R.; Welton, T. The role of hydrogen bonding in controlling the selectivity of Diels-Alder reactions in room-temperature ionic liquids. Green Chem. 2002, 4, 517-520. [CrossRef]

29. Bortolini, O.; De Nino, A.; Garofalo, A.; Maiuolo, L.; Russo, B. Mild Oxidative Conversion of Nitroalkanes into Carbonyl Compounds in Ionic Liquids. Synth. Commun. 2010, 40, 2483-2487. [CrossRef]

30. Yin, D.; Li, C.; Li, B.; Tao, L.; Yin, D. High Regioselective Diels-Alder Reaction of Myrcene with Acrolein Catalyzed by Zinc-Containing Ionic Liquids. Adv. Synth. Catal. 2005, 347, 137-142. [CrossRef]

31. Welton, T. Room-Temperature Ionic Liquids. Solvents for Synthesis and Catalysis. Chem. Rev. 1999, 99, $2071-2084$. [CrossRef] [PubMed]

32. Weingrtner, H. Understanding ionic liquids at the molecular level: Facts, problems, and controversies. Angew. Chem. Int. Ed. 2008, 47, 654-670. [CrossRef] [PubMed]

33. Wu, B.; Liu, W.W.; Zhang, Y.M.; Wang, H. Do We Understand the Recyclability of Ionic Liquids? Chem. Eur. J. 2009, 15, 1804-1810. [CrossRef] [PubMed]

34. Sarhan, A.A.O.; Bolm, C. Iron(III) chloride in oxidative C-C coupling reactions. Chem. Soc. Rev. 2009, 38, $2730-2744$. [CrossRef] [PubMed]

35. Correa, A.; Mancheno, O.C.; Bolm, C. Iron-catalysed carbon-heteroatom and heteroatom-heteroatom bond forming processes. Chem. Soc. Rev. 2008, 37, 1108-1117. [CrossRef] [PubMed]

36. Bolm, C.; Legros, J.; le Paih, J.; Zani, L. Iron-Catalyzed Reactions in Organic Synthesis. Chem. Rev. 2004, 104, 6217-6254. [CrossRef] [PubMed]

37. Yuan, Y.; Chen, F.; Zhao, D.B. Iron-catalyzed efficient three-component allylation of imine in aqueous media. Appl. Organomet. Chem. 2009, 23, 485-545. [CrossRef]

38. Bitterlich, B.; Schroder, K.; Tse, M.K.; Beller, M. An Improved Iron-Catalyzed Epoxidation of Aromatic and Aliphatic Olefins with Hydrogen Peroxide as Oxidant. Eur. J. Org. Chem. 2008, 29, 4867-4870. [CrossRef]

39. Iovel, I.; Mertins, K.; Kischel, J.; Zapf, A.; Beller, M. An Efficient and General Iron-Catalyzed Arylation of Benzyl Alcohols and Benzyl Carboxylates. Angew. Chem. Int. Ed. 2005, 44, 3913-3917. [CrossRef] [PubMed] 
40. Kischel, J.; Jovel, I.; Mertins, K.; Zapf, A.; Beller, M. A Convenient $\mathrm{FeCl}_{3}$-Catalyzed Hydroarylation of Styrenes. Org. Lett. 2006, 8, 19-22. [CrossRef] [PubMed]

41. Vidis, A.; Ohlin, C.A.; Laurenczy, G.; Esters, E.K.; Sedelmeier, G.; Dyson, P.J. Rationalisation of Solvent Effects in the DielsðAlder Reaction Between Cyclopentadiene and Methyl Acrylate in Room Temperature Ionic Liquids. Adv. Synth. Catal. 2005, 347, 266-274. [CrossRef]

42. Bini, R.; Chiappe, C.; Mestre, V.; Pomelli, C.; Welton, T. A theoretical study of the solvent effect on Diels-Alder reaction in room temperature ionic liquids using a supermolecular approach. Theor. Chem. Acc. 2009, 123, 347-352. [CrossRef]

43. Tiwari, S.; Khupse, N.; Kumar, A. Intramolecular Diels-Alder Reaction in Ionic Liquids: Effect of Ion-Specific Solvent Friction. J. Org. Chem. 2008, 73, 9075-9083. [CrossRef] [PubMed]

44. Fernandes, A.M.; Rocha, M.A.A.; Freire, M.G.; Marrucho, I.M.; Coutinho, J.A.P.; Santos, L.M.N.B.F. Evaluation of Cation-Anion Interaction Strength in Ionic Liquids. J. Phys. Chem. B 2011, 115, 4033-4041. [CrossRef] [PubMed]

45. Chiappe, C.; Malvaldi, M.; Pomelli, C.S. The solvent effect on the Diels-Alder reaction in ionic liquids: Multiparameter linear solvation energy relationships and theoretical analysis. Green Chem. 2010, 12, 1330-1339. [CrossRef]

46. De Nino, A.; Maiuolo, L.; Merino, P.; Nardi, M.; Procopio, A.; Roca-López, D.; Russo, B.; Algieri, V. Efficient Organocatalyst Supported on a Simple Ionic Liquid as a Recoverable System for the Asymmetric Diels-Alder Reaction in the Presence of Water. ChemCatChem 2015, 7, 830-835. [CrossRef]

47. Bortolini, O.; De Nino, A.; Garofalo, A.; Maiuolo, L.; Procopio, A.; Russo, B. Erbium triflate in ionic liquids: A recyclable system of improving selectivity in Diels-Alder reactions. Appl. Catal. A Gen. 2010, 372, 124-129. [CrossRef]

(C) 2018 by the authors. Licensee MDPI, Basel, Switzerland. This article is an open access article distributed under the terms and conditions of the Creative Commons Attribution (CC BY) license (http:/ / creativecommons.org/licenses/by/4.0/). 